ФТИ-2019

\title{
ESTIMATE THE ABSOLUTE EFFICIENCY BY MATLAB FOR THE NaI(TI) DETECTOR USING IAEA-314
}

\author{
Hesham M.H. Zakaly ${ }^{1,2}$, Mohamed A. Uosif ${ }^{1,3}$, Shams Issa ${ }^{1.4}, \underline{\text { Mujahed Saif }}^{*}$, \\ Mahmoud Tammam ${ }^{1}$, Atef El-Taher ${ }^{1}$ \\ ${ }^{1}$ Faculty of Science, Al-Azhar University, Assuit Branch, Egypt \\ ${ }^{2}$ Institute of physics and technology, Ural Federal University, Yekaterinburg, Russia. \\ ${ }^{3}$ Physics Department, College of Science, Al Jouf University, KSA \\ ${ }^{4}$ Physics Department, College of Science, Tabuk University, KSA \\ "E-mail: mujahed@azhar.edu.eg
}

This works amid to calculating the absolute efficiency at any interesting $\gamma$-energy in the energy range between 10 and 1764 keV.by using fit function which has been developed to calculate theoretically the absolute $\gamma$-ray detection efficiencies of a cylindrical $\mathrm{NaI}(\mathrm{Tl})$ crystal. Efficiency of the $\mathrm{NaI}(\mathrm{Tl})$ calculator is a program built in MATLAB by the author of this paper to make it easier to calculate the efficiency of standard source. The absolute $\gamma$-ray detection efficiencies have been calculated for detectors 3" x 3" inches NaI(Tl) crystal. The absolute efficiency of the NaI (Tl) detector was calculated using standard sources (IAEA-314) which have known activity of ${ }^{226} \mathrm{Ra}$ $\left(732 \mathrm{Bqkg}^{-1}\right)$ and ${ }^{232} \mathrm{Th}(17.8 \mathrm{ppm})$. In this calculation, experimental and theoretical efficiencies have been calculated.

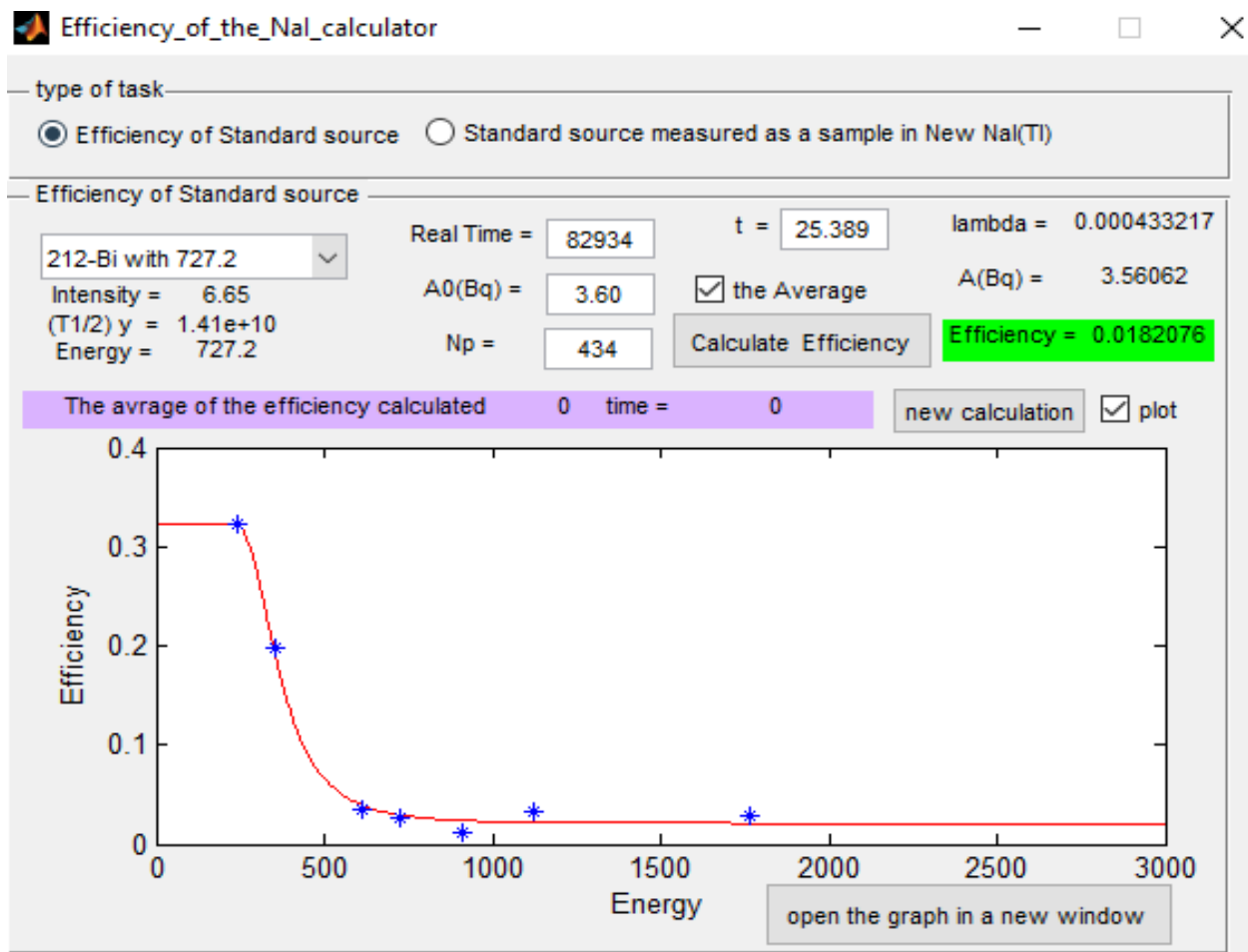

Fig 1. Full energy peak efficiency as a function of gamma ray energy for a typical $\mathrm{NaI}(\mathrm{Tl})$ detector for standard source (IAEA-314) which have known activity of 226Ra (732 Bqkg-1) and $232 \mathrm{Th}(17.8 \mathrm{ppm})$ 
The uncertainties of efficiency calibration have been calculated also for quality control. Measurements were performed with calibrated point source. Gamma-ray energies under consideration were $0.356,0.662,1.17$ and $1.33 \mathrm{MeV}$. Efficiency function was obtained by applying Weibull Model equation to the experimental efficiency data which give Best agreement between experimental and theoretical absolute detection efficiencies of $3 \times 3$-inch detector for gamma energy $[1,2]$.

1. Hamed Mohammed H M 2018 Natural Radioactivity along Red Sea Coastline, Egypt: Radiological Impact \&amp; Heavy Metals of Sediment Samples, Measurement (Egypt: Al-Azhar University)

2. El-Taher A, Zakaly H M H and Elsaman R 2018 Environmental implications and spatial distribution of natural radionuclides and heavy metals in sediments from four harbours in the Egyptian Red Sea coast Appl. Radiat. Isot. 131 13-22.

\title{
ТРАНСФОРМАТОРЫ ЛЬЮИСА С СОГЛАСУЮЩИМИ СУММАТОРАМИ
}

\author{
Семченко В.А. ${ }^{*}$, Кладухин В.В.
}

Институт электрофизики Уральского отделения Российской академии наук, Екатеринбург, Россия

"E-mail: laepr@iep.uran.ru

\section{LEWIS TRANSFORMERS WITH MATCHING ADDERS}

\author{
Semchenko V.A. ${ }^{*}$, Kladukhin V.V.
}

The Institute of Electrophysics of the Ural Division of the Russian Academy of Sciences (IEP UD RAS), Yekaterinburg, Russia

Annotation. The formation of high-powered nanosecond pulses by adding partial pulses within the Lewis transformer model is considered. The variants of the transformer design with matching adders of pulses are given.

Идея согласованного суммирования совокупности парциальных импульсов, распространяющихся по коаксиальным передающим линиям, для получения мощных импульсов высокого напряжения, была изложена в работе Льюиса [1], где сложение импульсов предлагается выполнять путём последовательного соединения выходов передающих линий между собой и с нагрузкой с использованием соединительных проводников. При этом предполагается, что соединения обладают необходимой электропрочностью, а их влияние на электродинамические процессы ничтожно.

Для сложения мощных высоковольтных импульсов наносекундной длительности характерны значительные длины соединений и связанные с ними большие 